JERZY ONISZCZUK ${ }^{1}$

\title{
Język pisany, reguła prawna \\ i abstrakcyjna moneta - archaiczne początki myślenia naukowo-filozoficznego
}

\section{Streszczenie}

Ważny dla naukowego i filozoficznego sposobu myślenia jest problem okoliczności, które wpłynęły na wykształcenie takiego typu rozważań, różnego od objaśniania rzeczywistości za pomocą mitologicznych wierzeń. Sensem umysłowych poszukiwań człowieka filozofującego okazał się namysł nad regułą, nad kierującą wszystkim zasadą, tj. zarówno światem naturalnym (kosmosem), jak i relacjami między ludźmi. Doszło do tego sposobu myślenia po tym, gdy pojawiła się potrzeba i możliwość spisania (ustanowienia) abstrakcyjnych norm prawa (nomos) dla pewności i sprawdzalności orzecznictwa, dla obrotu gospodarczego, a zwłaszcza dla własności (prawo cywilne), wartość której wyrażono abstrakcyjnie w pieniądzu monetarnym. Były to znaczące okoliczności dla zainicjowania i rozwoju myślenia naukowo-filozoficznego (abstrakcyjnego). Innymi fundamentalnymi warunkami rozwoju nauki i filozofii była wolność, równość i uznanie dla inności, a także nieortodoksyjny charakter wierzeń (mitów). Te zapewniała zaś obywatelska, kosmopolityczna i rozwinięta gospodarczo polis, zwłaszcza demokratyczna. Owe warunki rozwoju nauki i okazały się uniwersalne i ponadczasowe.

Słowa kluczowe: filozofia, nauka, abstrakcyjna norma, polis, pieniądz monetarny, wartość symboliczna, język pisemny, prawodawca, nomos i physis.

1 Prof. dr hab. Jerzy Oniszczuk - kierownik Katedry Administracji Publicznej Szkoły Głównej Handlowej; e-mail: jerzy.oniszczuk@sgh.waw.pl; ORCID: 0000-0003-4526-7334. 
JERZY ONISZCZUK

\title{
Writing, Legal Rule and Abstract Coin - the Archaic Beginnings of Scientific and Philosophical Thought
}

\begin{abstract}
Important for the scientific and philosophical mode of thought is the issue of circumstances that lead to the emergence of such type of reflection, different from traditional ways of explaining the reality by mythological beliefs. The spiritual search of a philosophising man turned out to be a reflection upon rule, upon the all-governing principle, i.e. both the natural world (cosmos) and the relations between people. This mode of thought evolved when a need and possibility for writing down (setting out) abstract legal norms (nomos) for the sake of certainty and verifiability of judgments arose. It was vital also for the trade and in particular for ownership (civil law), whose value was abstractly expressed in monetary money. These were the crucial factors in the initiation and development of scientific and philosophical (abstract) thought. Other fundamental conditions for the development of science and philosophy included liberty, equality and respect for otherness, as well as the non-orthodox character of beliefs (myths). These were ensured by the civic, cosmopolitan and economically developed polis, particularly the democratic one. Such conditions for the development of science and philosophy have proved to be universal and timeless.
\end{abstract}

Keywords: philosophy, ancient Greece, ancient Greek law, polis, science, abstract norm, monetary money, symbolic value, written language, lawgiver, nomos, physis. 


\section{Wstęp. \\ Przyczyny pojawienia się filozoficznego sposobu myślenia}

Ważny dla naukowego i filozoficznego sposobu myślenia jest problem okoliczności, które wpłynęły na wykształcenie owej niezwykłej refleksji, tak różnej od tradycyjnego objaśniania rzeczywistości za pomocą wierzeń. Zapewne musiało zdarzyć się coś, co wywołało nową jakość w rozumowaniu, dzięki której przekroczono granice tradycyjnego, mitycznego opisu świata i miejsca ludzi. Wyraźnie, po raz pierwszy inaczej niż w mitach, które dostarczały pewnych prawd o świecie i reguł służących porządkowaniu kosmosu, na rzeczywistość spojrzeli tzw. archaiczni greccy filozofowie przyrody. Korzystając z obserwacji, ale też używając jeszcze mitów, zaproponowali oni racjonalny namysł, przełamujący cechujące się naiwnością objaśnienia mityczne.

Wyniki owych ewoluujących koncepcji filozoficznych coraz bardziej przeciwstawiały się wcześniejszym poetyckim opowieściom - mitom, w których świat kształtowały bóstwa. Podejście archaicznych myślicieli różniło się nie tylko od jakiegoś „prostego” objaśniania, religijnej narracji, ale - co jest tu szczególnie ważne - także od sposobu myślenia wcześniejszych rozwiniętych cywilizacji Wschodu czy Egiptu. I właśnie ów fakt istnienia starszych kultur, niż grecka, powodował też stawianie kwestii, dlaczego to nie one wytworzyły naukę i filozofię. Dla wykształcania się filozoficznego sposobu myślenia fundamentalne znaczenie ma więc pytanie o przyczyny pojawienia się filozoficznego sposobu myślenia w archaicznej Grecji, tj. określanego jako niezależne spekulatywne racjonalizowanie.

Wskazuje się na wiele czynników, które wpływały na racjonalizowane objaśnienia świata. Wśród nich zwykle wymienia się zwłaszcza: podróżowanie i handel grecki w regionie Morza Śródziemnego, charakter greckiej religii (politeizm), wykształcanie się społecznych struktur polis oraz rozwój pisemnej formy języka², a także ekspansję Greków w postaci zakładania kolonii na Wschodzie i Zachodzie. Warunki te miały istotnie sprzyjać zwłaszcza wykształceniu się niezależnego, racjonalizującego sposobu myślenia. I to myślenie, określane jako logocentryczne, zwykle wskazywane jest jako charakteryzujące kulturę obszaru greckiego.

2 G. Stamatellos, Introduction to Presocratics, Malden, Ma.-Oxford 2012, s. 4; W. Lengauer, Religijność starożytnych Greków, Warszawa 1994, s. 11-43. 
To w kulturze greckiej miało dojść do wytworzenia logosu i rozumnej, spójnej refleksji oraz przekonanie o wartości samodzielnego myślenia. Wobec powyższego kwestią jest, jak w owej Grecji mogło dojść do ukształtowania tej kultury logocentrycznej ${ }^{3}$. To w obszarze kultury greckiej doszło do zaproponowania wizji zasady (arche), która jest różna zwłaszcza od kultury religijnej Persów i „egipskiego hermetyzmu". Joński Milet (kolonia grecka z ok. X w. p.n.e.) miał najpierw wykazywać ową inność Greków zwłaszcza wobec Persów, zaś później aktywność Pitagorejczyków ${ }^{4}$ w obszarze tzw. Wielkiej Grecji miała wpływać na wykształcanie nauk i wiedzy cechującej się odrębnością od dorobku kapłanów egipskich ${ }^{5}$. Można przypomnieć, że to w Milecie pojawiły się racjonalizujące objaśnienia wszechświata i mechanizm ciągłych rozumowych krytyk wcześniejszych koncepcji przez późniejsze. U podstaw tej praktyki umieszczane jest zwłaszcza otwarcie na rozmaite idee. Grecy dokonywali wielu zapożyczeń z wyżej rozwiniętych kultur, ale nie objęły one systemu wierzeń, chociaż niektóre wielkie systemy np. Egiptu i Mezopotamii określały nawet pochodzenie świata, jak i boski panteon. Pojawiła się świadomość różnorodności w tym zakresie i zaczęto zastanawiać się nad mnogością wierzeń, znaczeniem religii własnych i innych ludów, dochodząc do momentu, gdy została zainicjowana analiza religii ze względu na ich wartość przekonywania do wizji kosmosu i zdolność objaśniania rzeczywistości. Konsekwencją tych namysłów miał być niedostatek satysfakcji z tradycyjnych wyjaśnień i oczekiwanie na takie opisy, które lepiej przedstawią wszechświat. I na owe oczekiwania, tj. swoiste zapotrzebowanie społeczne (raczej nielicznych), odpowiedziały indywidualne wizje objaśniające kilku Milezyjczyków. Uczynili to, gdyż, jak wspomniano, pojawiła się pewna przestrzeń do rozważań i swoboda do zaprezentowania bardziej odważnych, dążących do przekonania wyobrażeń o świecie. Wiarygodności zaś tym objaśnieniom miało dostarczyć rewolucyjne novum, tj. racjonalność. Na prawdziwość opisu wpływało więc spełnianie przez nie kryterium racjonalności.

Pojawienie się nowego racjonalizującego i opierającego argumenty na obserwacji myślenia, określonego jako filozofia, możliwe okazało się z uwagi na wystąpienie w archaicznej Grecji specyficznych warunków kulturowych, ekonomicznych, społecznych, politycznych i prawnych. Co niezwykle istotne, do wytwarzania myślenia filozoficznego konieczne jest istnienie szeregu wolności (a zwłaszcza swobody myślenia i tolerancji dla niej), a te pojawiły się po raz pierwszy w greckich poleis. Nie dostrzega się, aby ów stan był doświadczeniem społeczności, które

\footnotetext{
3 G. Szulczewski, Aporie filozofii a kondycja racjonalizmu, Warszawa 2006, s. 40.

4 J. Oniszczuk, Użyteczność wiedzy, władzy, państwa i prawa w poszukiwaniach pitagorejskich, „Państwo Prawne" 2015, 1(5), s. 7-57.

5 G. Szulczewski, op. cit., s. 60.
} 
wcześniej tworzyły różne kultury. Nadto dowodzi się, że pojawienie się pewnego poziomu tych wolności nastąpiło najpierw w koloniach greckich, a nie w Grecji macierzystej. I początki poszukiwań filozoficznych mają miejsce właśnie w najstarszych koloniach na Wschodzie (Milet), a następnie na Zachodzie (Wielka Grecja). To w Jonii pojawiła się pierwsza próba objaśnienia rzeczywistości przyrodniczej, wszelkich bytów drogą rozumową dla faktu samego teoretycznego poznania. Jońscy i następnie italscy filozofowie próbują w ujęciu kosmologii objaśnić całość istniejących bytów, sprowadzając je rozumowo do „zasady” czy kilku zasad. Późniejsza kontynuacja i niezwykły rozwój filozofii w Atenach, a nie np. Sparcie, także wiązane są z wyjątkowym poziomem wolności, którym cieszyli się obywatele Aten ${ }^{6}$. Można powiedzieć, że te warunki swoiście „oczekiwały” na ludzi, którzy skorzystają ze „swobód”, aby postawić pytania dotyczące obrazu rzeczywistości i podejmą spekulacji w tym zakresie. Do powyższej uwagi należy dodać ważną okoliczność znacznego osłabienia oddziaływania zwyczajów metropolii po przeniesieniu do kolonii. To najpierw w koloniach podjęto spisywanie prawa, m.in. dlatego, że w nowych warunkach występowały trudności z praktykowaniem zwyczajowych reguł, zwłaszcza, gdy np. na kolonię wpływ miała nie tylko jedna metropolia. W każdym razie w świecie kolonii panował inny, mniej „obciążony” i ożywczy duch niż ten w odległej metropolii z jej konserwatywnymi prawami zwyczajowymi i rytuałami. I zapewne w tym świecie odwaga ryzykowania i zgoda na to była większa niż w metropoliach.

Najogólniej mówiąc, Grecy, podróżując do innych, odległych światów i przebywając w koloniach Azji Mniejszej, Italii oraz Sycylii, aby przetrwać czy odnieść sukces, musieli wykazywać dużo większą elastyczność, dostosowanie do nowych warunków. Ich własne normy społeczne i religijne nie miały przy tym charakteru ortodoksyjnego, który uniemożliwiałby uznawanie ważności innych reguł i prawd. Ale równocześnie zachowywali pewien rdzeń elastycznej wspólnotowej opowieści, który towarzyszył im zapisany w tekstach poetyckich. Z Grekami podążała też pewna tradycja prawna wspólnoty i jej organizacji. W tych warunkach na pytanie: "dlaczego" objaśnienie typu: „bo tak było zawsze”, odwołujące się do określonego nakazu określonego bóstwa czy polegające na przecinającej kwestię absolutnie pewnej odpowiedzi „najmądrzejszego" władcy raczej nie było akceptowane. Szukanie zatem objaśnienia w pluralistycznym środowisku kolonii wymagało argumentu przekonywania, gdyż wolnych i równych autorytetów „formalnych” przedstawiających swoje opowieści mogło być wiele. Objaśnienia i wskazania w świecie różnych mitologii, bóstw i ich nakazów traciło moc sprawczą. Siłą faktu do rozmowy i zrozumienia konieczne było wzajemne uznanie partnerstwa innego człowieka i poszu-

6 G. Reale, Historia filozofii starożytnej, t. 1, Lublin 2008, s. 20, 52. 
kiwanie przekonania rozumowego. Myślenie przedfilozoficzne pojawiło się w następstwie pluralizmu prawd mitycznych, a zatem w kwestionowaniu pewności objaśniającej mitów, a także w krytyce autorytetów poetycko-mitologicznych, zwłaszcza Homera.

\section{Alfabet i rozwój pisemnej formy języka. Nauczanie}

Ważny czynnik wykształcenia kultury, a więc i skodyfikowanego prawa oraz przedstawienia poezji przedarchaicznej, prawa czy myśli filozoficznych stanowiła pisemna (literowa) forma języka. Pojawienie się pisma (VIII w.) traktowane jest jako kluczowy moment dla wykształcenia się tzw. epoki archaicznej w literaturze, chociaż w obszarze filozofii owa epoka rozpoczyna się wraz z pierwszym filozofem-naukowcem, a trwa do pojawienia się pierwszej koncepcji charakterystycznej dla tzw. epoki klasycznej, tj. tej, która racjonalność wyposażyła w klucz moralny (Sokrates). Należy tu dodać, że starożytna legenda głosiła, że mityczny poeta i muzyk Linos z Teb przekształcał alfabet fenicki w grecki; ; pismo, o którym tu mowa, nie było jednak pierwsze na terenie Grecji.

Wcześniejszy, najstarszy język grecki wykształcił się w II tysiącleciu p.n.e. Wyewoluował on z języka indoeuropejskiego plemienia, które przybyło na teren Grecji w III tysiącleciu (ok. 2100 r.). W słownictwie greckim odnajduje się wiele słów podbitej nieindoeuropejskiej ludności. Najstarsze świadectwa języka greckiego pochodzą z początku XIV w. p.n.e. Są to teksty pisma sylabicznego - tzw. linearne B w odróżnieniu od starszego pisma linearnego A, tzw. kreteńskiego, które poprzedzone było przez pismo obrazkowe (z ok. 2000 r. p.n.e.). Po wielu wiekach przerwy w używaniu języka pisanego i jego zapomnieniu w Wiekach Ciemnych ponownie pojawiają się tekstowe świadectwa języka dopiero w VIII w. p.n.e. Teksty te są stworzone za pomocą pisma alfabetycznego uzyskanego od Fenicjan. Natomiast pismo wcześniejsze - linearne B pojawiło się po przejęciu starszego systemu pisma kreteńskiego (A) przez mykeńskich zdobywców wyspy (XV w.). Wówczas miało dojść do przemiany pisma A (dostosowania do wyrażania języka mykeńskiego), przy czym nie ma pewności czy wykształcenie pisma B nastąpiło na Krecie czy już na Peloponezie. Z zachowanych tabliczek pisma linearnego B z XIV-XIII w. (np. Knossos, Pylos, Teby) wynika, że występuje w nich jednakowa forma języka greckiego, tzw. dialekt achajski. Po upadku kultury mykeńskiej miało dojść do

7 I. Krońska, w: Diogenes Laertios, Żywoty i poglądy słynnych filozofów, Warszawa 2006, s. 6, przypis 2. 
zróżnicowań w dialekcie ${ }^{8}$ W każdym razie na obszarze kultury mykeńskiej używany był język grecki ${ }^{9}$.

Pisemna forma języka greckiego (sam język, jak wspomniano, wykształcił się w drugim tysiącleciu p.n.e.), która pojawiła się po Wiekach Ciemnych, miała fenickie (semickie) pochodzenie. Wcześniejsza zaś faza rozwoju pisma fenickiego wiązana jest z Syrią i Palestyną (obszar zachodniosemicki). Fenicjanie uprościli wcześniejsze pismo, które kierowało się zasadą sylabiczną i alfabet ich pisma liczył 22 znaki $^{10}$. Termin ",alfabet” pochodzi z języka fenickiego i składa się z nazw dwóch pierwszych znaków tego pisma, tj. „alef” i „bet”. Od fenickiego alfabetu niewiele różni się ten przyjęty przez Greków, jeżeli chodzi o kształt liter i porządek. Ale system semicki nie był w pełni pismem fonetycznym, gdyż nie miał jeszcze osobnych znaków dla samogłosek, co oznacza, że czytający interpretował, który z możliwych dźwięków odpowiada kontekstowi. Zatem innowacja grecka polegała na wprowadzeniu przez Greków osobnych znaków dla samogłosek (a, e, i, o, u) i oznaczeń tych spółgłosek, których nie było w języku semickim (ph, kh). Sprawiło to, że pismo - zasadniczo charakteryzowane jako uproszczone pismo sylabiczne - przekształciło się $\mathrm{w}$ pismo alfabetyczne. W systemie tym bowiem po raz pierwszy doszło do rozdzielenia wszystkich istotnych dźwięków mowy, tj. samogłosek i spółgłosek oraz przypisania im odpowiednich znaków (liter). Ten zabieg spowodował, że nowy system okazał się do tego stopnia elastyczny, iż korzysta z niego większość współczesnych języków. Podkreśla się też jako ważne to, iż system grecki ma zastosowanie do języków, które cechuje „»wymawianie« w zwykłym sensie tego słowa". Ta innowacyjna adaptacja systemu fenickiego miała dokonać się w grecko-fenickiej społeczności, istniejącej w miejscu, z którego łatwo i szybko pismo mogło dotrzeć do całej Grecji (bezklasowa powszechność języka pisanego).

8 B. Bravo, E. Wipszycka, Historia starożytnych Greków, t. 1, Do końca wojen perskich, Warszawa 1988, s. 19-20, 74-75, 77. Dostrzega się językową jednolitość tekstów z 2. poł. II tysiąclecia określanych jako dialekt achajski (od używanego przez Homera pojęcia Achajowie). Porównanie języka z tabliczek z XIV-XIII w. i pochodzącego z I tysiąclecia prowadzi do wniosku, że ten starszy zbliżony jest zwłaszcza do dialektów arkadyjskiego, cypryjskiego i nieco mniej do eolskiego. Po XII w. z dialektów achajskich pod wpływem doryckich wykształciły się dialekty, z których z kolei powstały dialekty attycki i jońskie (w I tysiącleciu). Z przemieszczaniem ludności w XI do IX w. przemieszczały się dialekty jońskie i doryckie na wybrzeże Azji Mniejszej. Jak przypomina A. Krawczuk (Mity, mędrcy, polityka, Warszawa 1975, s. 63 i 67) w ruinach Knossos w 1900 r. znaleziono swoiste archiwum pałacowe w postaci glinianych tabliczek zapisanych pismem linearnym B. Podobne archiwum odnaleziono w Pylos w 1939 r. (z tego miasta miał pochodzić homerycki Nestor). W Mykenach odnaleziono tylko kilkadziesiąt tabliczek. Pismo B znalazło się też na amforach odkrytych w Tebach, Mykenach i Tirynsie.

9 J. Chadwick, Odczytanie pisma linearnego B, Warszawa 1964.

10 Inne pisma: np. akadyjskie pismo sylabiczne liczyło 285 znaków, mykeńskie pismo linearne B ujmowało ponad 80 znaków, zaś greckie pismo sylabiczne pochodzące z Cypru - 56 . 
Jako przykładowe miejsce takiego ośrodka językotwórczego podawana jest grecka faktoria handlowa ${ }^{11}$ Al Mina (na wybrzeżu u ujścia Orontesu w Syrii), z której przez wyspy pismo mogło dotrzeć do Grecji kontynentalnej i dalej (pogląd ten nie ma jednak wystarczająco pewnego uzasadnienia). Konsekwencje wspomnianej modyfikacji języka okazały się prawdziwie rewolucyjne i to nie tylko dzięki szybkiemu rozpowszechnieniu się samego alfabetu także poza Grecją, tj. w Italii, gdzie wprost i poprzez kulturę Etrusków dotarła do Rzymu, aby później z jego „spuścizną rozprzestrzenić się w czasach nowożytnych na całą Europę"12. Co do istoty bowiem, alfabet grecki i składnia wytworzyły mechanizm sprzyjający precyzji i komunikacji w abstrakcyjnym myśleniu oraz za pomocą kategorii ${ }^{13}$. Można tu dodać, że na początku wspomnianego wykształcenia systemu języka pisanego istniały dwie główne grupy odmian tego języka tj.: wschodnia (Jonia, wyspy Morza Egejskiego, Korynt, Megara, Argos) i zachodnia (pozostała część obszaru greckiego). Przejście Aten z grupy zachodniej do wschodniej nastąpiło w ramach tzw. reformy Euklejdesa u schyłku V w. p.n.e., co ze względu na znaczenie Aten sprawiło, że odmiana wschodnia przyjęła się w świecie greckim. Z kolei wariant zachodni leży u podstaw języka łacińskiego ${ }^{14}$.

Najstarsze ślady istnienia greckiego zapożyczonego alfabetu, jak wspomniano, sięgają ok. 750 r. p.n.e. ${ }^{15}$, ale też Grecy szybko dostrzegli ogromną użyteczność wynalazku pisma, które do ok. 650 r. p.n.e. stało się dosyć powszechnie znane w Grecji. Można tu też odnotować, że pojawiły się poglądy, niepotwierdzone, sytuujące początki wykształcania alfabetu greckiego ok. 850 r. p.n.e., a nawet wcześniej. Z alfabetem fenickim mieli zetknąć się bowiem najpierw Grecy z Eubei (IX w.) i oni - założyciele Pithekusaj - mieli wprowadzić pismo na Zachód. Ale też pojawiły się poglądy o możliwości istnienia starszych odmian alfabetów greckich, gdyż znaki niektórych miały przypominać znaki fenickie nieużywane już w XI w. ${ }^{16}$.

11 Faktoria handlowa (emporion) była osadą zakładaną przez grupy greckich kupców pochodzących $\mathrm{z}$ różnych miejsc. Faktoria inaczej niż kolonia nie powstawała w drodze ceremoniału założycielskiego. Takie osady powstawały na obrzeżach rozwiniętych państw, np. Egiptu.

12 O. Murray, Narodziny Grecji, Warszawa 2004, s. 127-131.

13 G. Stamatellos, op. cit., s. 4.

14 B. Bravo, E. Wipszycka, op. cit., s. 117.

15 Za najstarszy zabytek pisma uznawany jest ułamek naczynia z ok. 750 r. i tzw. „czara Nestora” z ok. 740-725. Ten drugi zabytek pochodzi z wyspy Pithekussaj (obecnie Ischia koło Neapolu). Na tej czarze znajduje się tekst poetycki napisany heksametrem: „Kto się tylko napije z pucharu tego, to zaraz/ chwyci go żądza przemożna Afrodyty pięknie wieńczonej". Na podstawie tego i innych tekstów (np. na wazie znalezionej w Atenach datowanej na lata 730-720) dowodzi się, że charakter napisów i pomysł oraz sposób umieszczania ich umożliwia pogląd, że alfabet był już wcześniej w użyciu. (Zob. B. Bravo, E. Wipszycka, op. cit., s. 115).

16 W. Lengauer, Starożytna Grecja okresu archaicznego i klasycznego, Warszawa 1999, s. 21. 
Jeżeli chodzi o dzieła literackie, które jako pierwsze pojawiły się w formie pisanej, to prawdopodobnie były to homeryckie poematy, a jeszcze większą pewność formy pisemnej przypisuje się dziełom Hezjoda i Archilocha. Zresztą właśnie czasy Hezjoda postrzegane są jako moment „niewątpliwego wzrost[u] znaczenia poezji pisanej". W formie pisanej pojawiają się listy zwycięzców olimpijskich (776 r.), daty założenia kolonii na Sycyli (734 r.), lista ateńskich urzędników (683 r.), prawa Zaleukosa w italskiej kolonii Lokrach (Lokroi) Epizefyryjskich (ok. 650 r. p.n.e.), prawa Drakona z Aten (ok. 625 r.). Z uwagi na konieczność częstego przedstawiania i sprawdzania treści prawa właśnie ono okazało się tym rodzajem złożonego dokumentu publicznego, który wymagał spisywania. Natomiast typową formę porozumiewania, codziennej komunikacji i wymiany informacji między Grekami stanowiła rozmowa. Przypuszcza się, że greckie społeczeństwo stało się w „pełni piśmienne" na początku IV w. p.n.e. ${ }^{17}$. Ale świadomość praktyczności języka pisemnego dowodzona jest na podstawie np. umowy zawartej pod koniec VI w. w osadzie Datalla z zawodowym pisarzem Spensithiosem, który miał pisać i przechowywać wiadomości w postaci dokumentów urzędowych ${ }^{18}$.

Do powyższych uwag należy dodać, że z pojawieniem się pisma w VIII p.n.e., aż niemal do końca IV w. p.n.e. lokalny dialekt poszczególnych miast był używany do tworzenia nieliterackich tekstów. Natomiast utwory literackie, począwszy od homeryckich i tych pochodzących od Hezjoda, tworzone były w języku poetyckim, który nie był w codziennym użyciu. Ten język był bowiem efektem wielowiekowej tradycji ustnych przekazów twórczości epickiej. U podstaw tego języka znajdują się starsze dialekty jońskie. Na dowód poetyckiego znaczenia tego języka przywoływany jest przykład języka poezji Hezjoda, który żył Beocji używającej dialektu eolskiego, a także jego ojca posługującego się tym samym dialektem używanym w Kymie (Azja Mniejsza), w której mieszkał. Otóż język Hezjoda nie jest językiem Beocji, ale językiem homeryckim. Późniejsi twórcy poematów epickich aż do końca starożytności posługiwali się językiem pierwowzoru gatunku literackiego. Język poematów Homera wpłynął na języki różnych gatunków literackich (elegii, lirykę, dramat). Twórczość pojawiła się w ogólnogreckim języku poetyckim nawiązującym do niektórych dialektów i wobec tego opisywana jest jako pozostająca w kolorycie nawiązującym do nich. Nigdy jednak język poezji nie był czystym dialektem danego miasta $^{19}$.

17 O. Murray, op. cit., s. 130-131, 137.

18 W. Lengauer, Starożytna Grecja..., s. 21.

19 B. Bravo, E. Wipszycka, op. cit., s. 21-22, 118 i powoływana praca: J. Chadwick, The Prehistory of the Greek Language. 
Z uwagi na okoliczność, że do pierwszych dzieł napisanych prozą został użyty dialekt joński (VI w.), przez pewien czas w nim tworzyli prozaicy bez względu na swe miejsce zamieszkania. W V w. podejście to zmienia się. Na przykład Tukidydes pod koniec $\mathrm{V}$ w. zaczął tworzyć $\mathrm{w}$ dialekcie attyckim. Powodem miał być m.in. rozwój twórczości mówców ateńskich, którzy nie byli nastawieni na pracę literacką, ale pisali po attycku powodowani względami codziennej praktyki. Jednak z uwagi na treść ich prac i społeczne znaczenie retoryki, a także rozwój szkół retorycznych, pisarstwa literackiego, dramatycznego i filozoficznego (od Platona począwszy), a wreszcie nowatorską treść dokumentów wytwarzanych przez instytucje demokracji ateńskiej, okazało się, że te różne normy formy wypowiedzi w dialekcie attyckim zaczęły nabierać dużego znaczenia. To w tym języku następuje rozwój greckiego życia umysłowego, do tego stopnia, że od połowy IV w. dialekt attycki z elementami jońskimi przybrał postać języka ogólnogreckiego, najpierw elit intelektualnych, a później obowiązującego w funkcjonowaniu urzędów i życiu codziennym Greków ${ }^{20}$.

W oparciu o ustalenia Harolda Innisa i Marshalla McLuhana traktujące komunikację międzyludzką jako podstawową siłę społeczną i zmiany w sposobie porozumienia jako zasadnicze „katalizatory stymulujące zarówno stosunki społeczne, jak i prywatne" pojawiło się antropologiczne studium Jacka Goody'ego i Iana Watta poświęcone cywilizacji greckiej, traktujące m.in. o znaczeniu pojawienia się pisma ${ }^{21}$. Uczeni podjęli próbę wykazania, że u podstaw większości zmian w archaicznej Grecji było pismo. To w nim odnaleziono powody „dążenia do demokracji, rozwoju logiki, racjonalizmu, sceptycyzmu, wzrostu indywidualizmu i alienacji osobniczej oraz zastąpienia prymitywnego, mitologicznego sposobu przedstawiania przeszłości krytyczną historiografią". To dzięki pismu pojawiła się nie tylko możliwość utrwalania regul, które wcześniej cechowała różnorodność i zmienność, ale udostępniania tych bardziej ustabilizowanych, wyraźnie określonych treści dużej liczbie ludzi. Z upowszechnieniem pisma następuje utrwalanie zasad prawnych i ograniczenie dowolności interpretacyjnej sędziów. W pisemności znajduje się bowiem swoisty mechanizm, który sprzyja ograniczeniu wieloznaczności, zmienności interpretacji uznawanej jako charakteryzujące tradycję ustną. Z ujawniania sprzeczności między treścią ujętą $\mathrm{w}$ formie pisemnej i funkcjonowaniem w pewnej rzeczywistości miał wykształcać się krytycyzm. U swojej podstawy miał on myśl o racjonalności, która rządzi publiczną i prywatną rzeczywistością. Pismo okazało się mieć zarówno znaczenie inicjujące, jak i sprzyjające fundamentalnym przemianom w Grecji. Sprzyjało wzrostowi roli poezji i rozwojowi tradycji epickiej.

20 B. Bravo, E. Wipszycka, op. cit., s. 22-23.

21 Za: O. Murray, op. cit., s. 135. 
W przypadku filozofii jońskiej zapisane wypowiedzi miały ułatwić precyzję kolejnych rozważań krytycznych, w historiografii zaś od mitografii za pomocą krytycznej oceny starych opisów doszło do wykształcenia historii. Natomiast podjęcie pisemnego kodyfikowania prawa sprzyjało jego pewności i trwałości oraz przełamywaniu przewagi ustroju arystokratycznego na rzecz systemów demokratycznych, które rozwinęły się $\mathrm{w} \mathrm{V}$ w. p.n.e. $\mathrm{W}$ każdym razie pismo miało istotne znaczenie dla wielu przemian, choć - jak zauważa Murray - nie oznacza to, że „umiejętność pisania stanowiła element tak istotny, iż uznać go trzeba za wystarczającą przyczynę (...) owych zmian"22.

Znaczenie następstw pojawienia się pisma bywa oceniane wedle kryterium celu, któremu służyła umiejętność pisania (Goody). Inaczej, niż w typowych przypadkach, w których pismo pełni funkcje związane $\mathrm{z}$ „istniejącymi formami życia społecznego", a zwłaszcza pozostaje w "szczególnym związku ze sferą religii i polityki", a więc zasadniczo wzmacnia i utrwala istniejący ustrój, to "greckie pismo rozwijało się w świeckiej atmosferze i w swoich początkach służyło przede wszystkim świeckim celom". Zatem m.in. z uwagi na brak kasty kapłańskiej (chroniącej dogmaty religijne) i w znacznym stopniu otwarty charakter systemu politycznego, zaistniały warunki do wspierania przez pismo wspomnianych tendencji świeckich. Tym uzasadnia się ważny wpływ pisma w sferze poezji, prawa czy zachowania pamięci ${ }^{23}$. Zapewne ta przyczyna sprzyjała pojawieniu się traktatów medycznych, matematycznych, czy tekstów dotyczących geografii i astronomii, a wreszcie dzieła Herodota na temat „historii ojców” (Dzieje).

Pomimo znaczących odmian i mnogości dialektów greckich różne ustalenia, poglądy czy reguły stały się ogólnie dostępne dzięki powszechnemu i ujednoliconemu językowi greckiemu używanemu zarówno w sferze publicznej, jak i prywatnej. Archaiczne polityczne i społeczne struktury budowane od VI w. p.n.e. miały znaczenie dla rozwoju wczesnej filozofii, jej pytań i mechanizmu dialogu. Ówczesne ogólne przemiany w greckim świecie, którym towarzyszyły polityczne ruchy i wykształcanie się demokracji miasta-państwa, sprzyjały różnorodności praktyki i zwyczajów, umożliwiały krytyczną refleksję, niezależne dowodzenie i podejmowanie decyzji. Rozwijająca się w tych warunkach edukacja zachęcała do rozważań. U podstaw edukacji literackiej znajdowały się opisy poetów okresu archaicznego (Homera i Hezjoda), a także przypisywane mitycznemu Orfeuszowi. Poezja ta była używana jako autorytatywny głos, aby wyrazić ludzki heroizm, boską działalność i strukturę naturalnego świata. Grecka edukacja i kultura ośmielała zatem do stawiania pytań i do rozmowy. W takim środowisku filozofowie archaiczni

\footnotetext{
22 O. Murray, op. cit., s. 135-137.

23 Ibidem, s. 137.
} 
oceniali, krytykowali i rozwijali tradycyjne wierzenia i namysł nad naturą kosmosu i ludzkiego życia. Znaczenie dla rozwoju poszukiwań filozoficznych miał też duch konkurencji (charakterystyczny dla kultury arystokracji), promowany przez Greków zwłaszcza za pomocą zawodów sportowych. Wydarzenia takie obejmowały także występy muzyczne i poetyckie. Najlepsi uczestnicy zawodów wyróżniali się nie tylko sprawnością fizyczną, ale również talentami umysłu. Duch umysłowej konkurencji odnajdywany jest w spornym argumentowaniu. Możliwość prowadzenia krytycznego dialogu traktowana jest jako ważny mechanizm uruchamiający filozoficzną refleksję. Myśliciele archaiczni pozostawali w krytycznym i twórczym filozoficznym dialogu ze swoimi nauczycielami i zwolennikami. Na przykład Anaksymander kwestionował kosmologiczny pogląd Talesa, sam zaś był krytykowany przez swojego ucznia Anaksymenesa. Heraklit nie przywiązywał znaczenia do szerokiego nauczania Pitagorasa i Ksenofanesa, natomiast mający podążać za nim Parmenides głosił odmienną od koncepcji Heraklita wizję stawania się i materialny monizm myślicieli jońskich. Paradoksy Zenona dotyczące ruchu i niekończącego się podziału materii zostały podjęte w inny sposób przez Empedoklesa i Demokryta. Wreszcie koncepcja rozumu Anaksagorasa została skrytykowana przez Sokratesa jako nieadekwatna. Jeszcze innym elementem wykształcania myślenia filozoficznego okazał się sposób wypowiedzi. Ekspresja za pomocą prozy stała się nowym środkiem wyrazu dla większości myślicieli archaicznych. Ferekydes z Syros przedstawiany bywa jako pierwszy, który stworzył dzieło prozą w filozoficznym kontekście, co było prawdopodobnie współczesne Bajkom Ezopa (620-560 r. p.n.e.). W VI w. p.n.e. Anaksymander i Anaksymenes pisali swoje prace (O naturze) prozą, jako formą bardziej odpowiednią dla przedmiotu aniżeli elegancki poetycki styl Homera i Hezjoda. Niektórzy myśliciele, np. Ksenofanes, Parmenides i Empedokles, odrzucali nowe narzędzie - prozę i posługiwali się wierszową miarą oraz stylem wcześniejszej formalnej poezji, dostosowując ją do swego sposobu myślenia ${ }^{24}$. Zwrot w kierunku prozy pojawia się jako dzieło jońskiego "oświecenia”, jako środek, który lepiej niż poezja spełnia wymagania filozoficzno-naukowych precyzyjnych i krytycznych analiz.

Jeżeli chodzi o ważną sprawę edukacji, to dopiero w okresie hellenistycznym pojawiają się szkoły publiczne. Wcześniej działały szkoły prywatne dla dzieci, natomiast możliwość bardziej rozwiniętego nauczania dorosłych towarzyszyła działalności ośrodków sportowych - gimnazjonów (gymnasia). W okresie przedhelleńskim znajdowały się one poza murami poleis. Natomiast później gymnasia w miastach stawały się ośrodkiem głównej instytucji publicznej jaką była efebia (ephebeia) -

24 G. Stamatellos, op. cit., s. 4-6. 
centrum wychowania obywatelskiego i wojskowego młodzieży ${ }^{25}$. Pismo otworzyło drzwi do rozwoju wielu obszarów, umożliwiło pojawienie się swoistego orzeczenia sądu w postaci tekstów, do których mogli sięgać ludzie, aby ustalić pewną sytuację czy treści obowiązujących publicznych praw. Jednak to dopiero z upowszechnieniem umiejętności pisania i czytania zostaje zniesiona pewna władza pisarzy - uczonych w piśmie. Dla powstawania samej filozofii i nauki nie miało to rewolucyjnego znaczenia, ale dla upublicznienia ich rezultatów oraz wpływu na rzeczywistość - ogromną.

Niejako na marginesie można odnotować, że w literaturze dostrzega się przydatność języka greckiego dla podjęcia filozofowania. Otóż z uwagi na swój charakter ma on nadawać się do spekulatywnych poszukiwań. Służyć temu ma używanie przez język grecki rodzaju nijakiego (neutrum) umożliwiające przedstawienie tego, „co jest intencjonalnym przedmiotem myśli (...) jako podmiot”. W owym neutrum oznaczającym coś wszechobecnego odnaleziono zapowiedź pojęcia, albowiem miałoby zawierać to, co „jest wspólne wszystkim rzeczom", a więc cechę, która ,jawi się w każdym bycie”. Jeszcze inna cecha języka greckiego dostrzegana jest w występowaniu „łącznika (-), stosowanie słowa »być« dla połączenia podmiotu z orzeczeniem, co tworzy strukturę zdaniową", i w ocenie Hansa Gadamera, „ten fakt jest momentem rozstrzygającym" ${ }^{26}$. Opinia ta nie jest jednak szerzej uzasadniona.

Niezależnie od cech konkretnych języków można powiedzieć, że język pisany umożliwił tworzenie tekstów. To dzięki nim możliwe stało się z jednej strony przedstawienie poglądu (autor) i odczytanie tego tekstu - z drugiej strony (odbiorca). Nie musieli być już w tym samym miejscu i czasie, aby uczestniczyć w rozwijającej się rozmowie. Owa rozmowa mogła mieć abstrakcyjny sens. Pisemny tekst umożliwił abstrakcyjne przedstawianie rozwiniętej refleksji i odczytanie jej z przemyśleniem oraz interpretacją.

\section{Prawodawca. Kodyfikacja prawa zwyczajowego. Konstytucje}

Prawo we wspólnotach greckich wychodzących z wieków ciemnych pojawiło się zanim dotarło do nich pismo (VIII w. p.n.e.). Znajdowało się ono w rękach władców (symbolizuje ich homerycki Agamemnon), a później arystokracji, która zarówno stanowiła prawo, jak i orzekała. Basileus (sędzia-król) wydawał wyroki (themistes), które odzwierciedlały bardzo swobodne podejście do prawa. Ale też np. w ujęciu

25 M.H. Hansen, Polis. Wprowadzenie do dziejów greckiego miasta-państwa w starożytności, Warszawa 2011, s. 162-163.

26 H.G. Gadamer, Początek filozofii, Warszawa 2008, s. 22 i powoływane tam prace: B. Snell oraz K. Reinhard. 
Hezjoda owe orzeczenia powinny być wydawane w myśl zasady sprawiedliwości (dike). Kwestią okazało się, co jest źródłem tej sprawiedliwości, a także to, jakie wyroki są z nią zgodne. Zatem w tym przypadku myśl o spisaniu praw (zwyczajów) miała na celu połączenie orzecznictwa sądowego ze sprawiedliwością ${ }^{27}$. Prawo, które spisano, nabywało specyficznego autorytetu.

Powszechnie podkreślane jest, że w epoce archaicznej wraz z cywilizacją wojskową hoplitów pojawiło się wyraźne żądanie pewności prawa i rozstrzygnięć arystokratycznych sędziów oraz sprawiedliwości takiego prawa. Temu najczęściej miało służyć spisanie prawa, choć nie było to jedyne uzasadnienie dla pisanego prawa. W każdym razie w spisanym prawie wyraźnie ujawniała się specyfika obywatelskości polis. Usztywniało ono system i umożliwiało dostrzeganie odmienności dotyczących prawa i ustroju różnych poleis. To więc w unormowaniach Sparty wprowadzono ascetyczne rozwiązania dla demokracji. Instytucje i prawo spartańskie służyły ukształtowaniu cech składających się na etos hoplity (zwłaszcza cnoty odwagi i dyscypliny) i treści polis ludzi „podobnych”. Inne rozwiązania niż we wzorcowej dla polis hoplitów Sparcie dla demokracji wolnościowej zaproponowało prawo w Atenach. Cechą ateńskiej demokracji było bardziej elastyczne podejście do spraw społecznych, a zwłaszcza zwrócenie uwagi na sprawiedliwość społeczną. Ale też to z normatywnym pojawieniem się i ciągłym ujawnianiem zróżnicowań obu podejść do demokracji miało wytworzyć się napięcie między nimi i w rezultacie wykształcenie specyficznego namysłu nad demokracją; miał ujawnić się filozoficzny wymiar demokracji. Inaczej mówiąc, to zwłaszcza rozmaitość rozwiązań normatywnych zainspirowała namysł filozoficzny nad ustrojem społecznym i człowiekiem w państwie. Ale też w powyższej, uproszczonej charakterystyce pojawia się i inny konflikt - między modelem propaństwowym, z upublicznionym obywatelem (w skrajnej postaci państwo totalitarne), a podejściem demokratycznym, u podstaw którego są prawa wolnej jednostki. Historia wskazuje, że w tym drugim chętniej chcą żyć ludzie nie tylko o nastawieniu twórczym.

Wspomniano, że fundamentalny dla sprawy spisania prawa w okresie archaicznym problem respektowania sprawiedliwości pojawił się w związku z niesprawiedliwościami rządzącej arystokracji. W pamięci społecznej, a zwłaszcza w poematach, obecna była myśl, że wcześniejsze, tradycyjne reguły obyczajowe znajdowały się w opiece króla, który otrzymał wiedzę o orzekaniu od Zeusa. U podstaw wyrokowania znajdowało się więc religijne uzasadnienie. Do takiego sprawiedliwego króla należało zapewnianie pomyślnego trwania natury. Przywoływany na rzecz charakterystyki „króla nieskazitelnego" fragment Odysei mówi, że tenże: „W bojaźni bożej, panując nad licznymi dzielnymi mężami podtrzymuje sprawiedliwość,

27 W. Lengauer, Starożytna Grecja..., s. 56. 
a czarna ziemia niesie pszenicę i jęczmień, drzewa są ciężkie od owoców, owoce nieustannie rodzą, morze dostarcza ryb z powodu dobrych rządów, a lud cieszy się pomyślnością dzięki niemu"28. Sprawiedliwy król zapewniał więc harmonię sił w przyrodzie, zaś niesprawiedliwy, ową harmonię naruszając, sprowadzał nieszczęścia. Dążność do kontynuowania wymiaru sprawiedliwości zaszczepionej przez boga przejawiali po ustąpieniu monarchii urzędnicy rządzącej arystokracji. Ale ich „pokrólewski” wymiar sprawiedliwości widocznie budził wiele zastrzeżeń, skoro np. Hezjod (Prace $i$ dnie) podjął krytykę wyroków sędziów arystokratycznych wskazując na ich niesprawiedliwość z punktu widzenia oczekiwań Zeusa. Z upływem czasu zanikała religijna podstawa wyrokowania. Jednocześnie narastająca świadomość społeczna niesprawiedliwych wyroków służących interesowi arystokracji sprawiła, że w ówczesnej Grecji pojawiło się, jak wspomniano, żądanie spisanie prawa obyczajowego. Liczono, że drogą porównywania wyroków z prawem spisanym będzie można kontrolować orzecznictwo ${ }^{29}$.

W okresie władzy arystokratów o prawie i sądach greckich krytycy twierdzili, że nie są legitymizowane przez boskie działania i ich zbiory nakazów (przykazań). Boski wkład Zeusa polegał tylko na dostarczeniu prawa do sądzenia i nadzorowaniu orzeczeń. Na rzecz tego spostrzeżenia przywoływane są procedury wyrokowania przez starszych opisywane przez Homera i Hezjoda oraz pogląd społeczny, że orzeczenia te powinny się sytuować się w pewnych granicach. Funkcją tak pojmowanego prawa było zwłaszcza przeciwdziałanie nadmiernej swobodzie sędziów czy nawet ich samowoli. Hezjod był wyrazicielem bardziej ogólnego poglądu, nie godzącego się z przypadkami niesprawiedliwego wyrokowania. To jego stanowisko wyraża spostrzeżenie, że sędziowie bywają oszukańczy i wypowiedź, iż wyroki sędziów sprawiają przykrość Dike ${ }^{30}$. Kodyfikacja prawa w formie pisemnej przede wszystkim umożliwiała zatem wyraźne ujawnienie i utrwalenie reguł prawa zwyczajowego, ale też wpłynęła też na stabilizowanie interpretacji sędziowskiej postrzeganej jako „wykrętna” i dowolna.

Szereg wspomnianych potrzeb zaowocowało pojawieniem się osoby tzw. prawodawcy (nomothetes) i ów prawodawca okazał się mieć w kulturze prawnej Grecji

28 Homer, Odyseja, (Ksiega XIX, w. 109-114 ), cyt. w: B. Bravo, E. Wipszycka, op. cit., s. 196. Zob. też ów fragment w: Homer, Odyseja, tłum. L. Siemieński, oprac. Z. Kubiak, Warszawa 1990, s. 291 (Pieśn Dziewiętnasta, w. 111-116).

29 B. Bravo, E. Wipszycka, op. cit., s. 196.

30 O. Murray, op. cit., s. 86-87, 95. „Nieraz gród cały cierpi z powodu jednego zbrodniarza,/ Który nie znając prawości zbrodnię po zbrodni powtarza", Hezjod, Prace i dnie, Wrocław 1952, s. 15-16; J. Oniszczuk, Hezjod: prefilozofia pracy, sprawiedliwości i hybris, [w:] M. Latos-Miłkowska, Ł. Pisarczyk (red.), Prawo pracy między gospodarka a ochrona pracy. Księga jubileuszowa Profesora Ludwika Florka, Warszawa 2016. 
ważne znaczenie. Na znaczenie i dzieło prawodawcy można spojrzeć z punktu widzenia rozróżnienia między regułami ustanowionymi przez niego, osobę o półboskiej mądrości, a ustawami uchwalanymi przez Zgromadzenie polis. O ile to drugie, w pewnym skrócie mówiąc, łatwo podlegało modyfikacjom, to akt prawodawcy był jak swoista konstytucja o stałej czy znacznej trwałości (np. prawa Likurga w Sparcie). Zatem prawo ustanowione przez prawodawcę mogło być zmienione również przez posiadającego odpowiednie upoważnienie kolejnego prawodawcę. Solon jako prawodawca miał opuścić Ateny na dziesięć lat, aby nie zostać zmuszonym przez tyrana do zmiany prawa ${ }^{31}$.

Najogólniejszy sens instytucji prawodawcy odnajdywany jest w dążności do ograniczenia wpływów arystokracji i utrzymania osiągnięć prawa zwyczajowego. Kwestią jest cel, sposób powołania prawodawcy i jego kompetencje. Jeżeli chodzi o cel powołania prawodawcy, to miał on dokonać kodyfikacji prawa i ująć je w formie pisemnej. Nie był to więc prawodawca "wymyślający" prawo, ale w zasadzie spisujący istniejące zwyczaje. Wybierany był z grona osób znających prawo i otrzymywał władzę dającą mu znaczną swobodę, jeżeli chodzi o traktowanie zastanej tradycji prawnej, jak i ogromną niezależność od poglądów ludu. Ta swoista władza absolutna sprzyjała uznaniu własnej mocy prawodawcy. Prawodawca nie uzasadniał swoich poczynań wpływami boskimi, ale odwoływał się w istocie „do własnego poczucia sprawiedliwości i wiary, jaką pokładała w nim cała wspólnota”. Zwykle przypisywany mu autorytet uwiarygadniał instytucje polis, przy czym bywało też, że traktowano go z powagą przysługującą półherosom, czy postrzegano go na podobieństwo „boskiego” założyciela kolonii. Zresztą szczególna sytuacja kolonii powodowała, że to $\mathrm{w}$ nich najwcześniej pojawili się prawodawcy ${ }^{32}$. W koloniach miał miejsce większy nacisk na spisywanie prawa, m.in. dlatego, że w nowych warunkach występowały trudności ze stosowaniem zwyczajowych reguł, zwłaszcza gdy np. na kolonię wpływ miała nie tylko jedna metropolia. Ale też na nowych terytoriach Grecy spotykali się z innymi kulturami, których elementy mogły wpływać na kolonistów. Zatem potrzebowano wspólnego zbioru praw. Wśród najstarszych prawodawców w koloniach wymieniani są: Zaleukos z italskiej kolonii Lokroi Epizefyryjskich (ok. 650 r. p.n.e.) i Charondas z Katany na Sycylii (koniec VII w. lub początek VI w. $)^{33}$. Natomiast w Grecji właściwej do grona prawodawców zaliczani są zwłaszcza Filolaos z Koryntu działający w Tebach (początek VI w.),

31 Herodot, Dzieje, Warszawa 2004, s. 28.

32 O. Murray, op. cit., s. 241-243.

33 Miał nadać prawa nie tylko Katanie, ale wielu poleis Sycylii, np. Leontinoi, Naksos, Himerze. Jego prawa miały być też używane w południowej Italii, na niektórych wyspach Morza Egejskiego i w Azji Mniejszej (Kapadocja). 
legendarny Likurg ze Sparty (VII w.), a w Atenach Drakon (w latach 621/620 p.n.e.) i nieco później Solon. Na Krecie ustawodawcą miał być pod koniec VII w. Epimenides. Wśród najstarszych prawodawców Arystoteles wymienia nieznanego Fidona z Koryntu, który miałby działać już VIII w., a także przywołuje legendarną postać Onomakritosa (Lokaryjczyka) z Krety ${ }^{34}$. Wśród tych prawodawców znaleźli się mędrcy jak Solon, ale też tyrani, jak Drakon czy Periander w Koryncie (625-585). Można tu odnotować, że niejednokrotnie akceptacja ludności dla tyrana wynikała z jego działań prawodawczych, albowiem wprowadzając spisane prawa, przełamywał arystokratyczne, swobodne podejście do zwyczajowej sprawiedliwości. Z akceptacją ludu spotykali się też tyrani wspierający prawo demokratyzujące stosunki społeczne, jak np. Pizystrat, w okresie władzy którego Ateny rządziły się prawem Solona. Tacy „demokratyczni” tyrani mogli wspierać się na władzy obywatelskiej armii hoplitów pragnących uznania swych zasług dla polis na równi z arystokracją.

Nieco rozwijając powyższą uwagę, można dodać, że pierwszy ze wspomnianych prawodawców - Zaleukos - miał zaproponować normy w sferze ochrony własności prywatnej, a także polityki i obyczajów. Nadto urzędnikom miał nakazać obiektywizm i ochronę ładu wewnętrznego. Z kolei Charondasowi przypisuje się wprowadzenie procedury sądowej, a także odpowiedzialności sądowej w przypadku złożenia fałszywego świadectwa. Filolaos unormował zasady dziedziczenia służące utrzymaniu określonej liczby działek ziemi (kleroi). Mityczny Likurg miał zaproponować regulację dotyczącą ustroju polis i miał być też twórcą zbioru podstawowych praw w Sparcie - Wielkiej Rhetry (co zostało jednak przez badaczy zakwestionowane). Dostrzega się, że z końca VII w. mogą pochodzić prawa z Dreros (Kreta) dotyczące działania organów publicznych ${ }^{35}$. W Atenach rola Drakona polegała na spisaniu zwyczajów ze wszystkich „dziedzin” prawa, a Solona na wprowadzeniu pewnej demokracji prawnej i sprawiedliwości społecznej. Arystoteles za godną odnotowania w przypadku Drakona uznał tylko surowość kar, natomiast pozytywnie oceniał prawodawstwo Solona jako ograniczające wpływy oligarchii, kończące niewolę ludu i przywracające prastarą demokrację. Także Pittakos z Mityleny (Lesbos) ok. 600 r. miał zostać powołany do spisania praw. I jako znamienne uznaje Arystoteles jego regulację, że „pijani, jeśliby kogoś pobili, mają większą karę ponieść aniżeli trzeźwi; ponieważ ludzie więcej dopuszczają się czynów gwałtownych po pijanemu niż na trzeźwo, więc nie brał pod uwagę pobłażania głoszącego, ze należy raczej przebaczyć pijanemu, ale wzgląd na korzyść społeczną"36.

\footnotetext{
34 Arystoteles, Polityka, Warszawa 2004, s. 55 (1265 b), przypis 26, s. 74 (1274 a).

35 W. Lengauer, Starożytna Grecja..., s. 56-57; Arystoteles, op. cit., s. 75 (1274 b).

36 Arystoteles, op. cit., s. 73 (1274 a), s. 75 (1274 b).
} 
Wspomniany proces kodyfikacji prawa zwyczajowego, jego zamiana w pisane prawo polis, trwał dosyć długo. To nowe prawo postrzegano jako fundament społeczności ludzkiej (Hezjod, Archiloch, Solon), jako usuwające swobodę interpretacyjną, a także zostało potraktowane w społeczeństwie jako swoistego rodzaju władcę (nomos basileus). To prawo, regulując ogromny zakres stosunków międzyludzkich, a nawet sprawy rodzinne i religijne, podporządkowało je obowiązkom obywatelskim, nadając też w ten sposób znaczenie sprawiedliwości (dikaiosyne). Transcendentny wymiar prawa spisanego pojawiał się w następstwie społecznego uznania, że odpowiada prawu naturalnemu, a wreszcie, że spisywał je prawodawca - osoba szczególna, o nadzwyczajnych właściwościach rozumu. Jednakże spory polityczne i walki w państwach oraz między nimi powodowały naruszenia prawa. Stąd problem nienaruszalności prawa przez ludzi okazał się mieć sens filozoficzny. Mianowicie dowodzenie konieczności przestrzegania prawa państwowego, od którego oczekiwano, że będzie zgodne z prawem natury (boskim), kierowało uwagę na sprawę sensu (istoty) prawa. Jednakże wobec osłabienia na początku VI w. religii bogów olimpijskich, a także niedoskonałości wizji jednorodnej natury wszechrzeczy, która traktowała człowieka jako element przyrody (Milezyjczycy), pojawiła się nowa propozycja racjonalności filozoficznej nawiązująca do orfizmu. Te nowe poszukiwania po raz pierwszy próbują nie tylko przedstawić regułę rządzącą kosmosem (zasadę), ale również podejmują sprawę człowieka jako cząstki we wszechświecie, relacji między kosmosem i jednostką (pitagoreizm) ${ }^{37}$.

Myślenie przedfilozoficzne zaznaczało konieczność życia w pewnej wspólnocie plemiennej czy później politycznej w ramach polis (Homer) będącej strukturą nadrzędną nad człowiekiem. Ten wymiar polis miała określać jej natura i prawa. Najstarsze poszukiwania filozoficzne, podążające za wcześniejszymi wyobrażeniami, próbowały racjonalizować normy kierujące całą rzeczywistością (kosmosem), formułowały więc prawa dotyczące przyrody, ale i wspólnoty oraz określały sytuację jednostki wobec przyrody i rzeczywistości społecznej. Te prawa natury nakazywały też człowiekowi, aby je przestrzegał. Najwcześniejsze poszukiwania filozoficzne nie wprowadzały jeszcze rozróżnień np. na prawa boskie, natury czy stanowione polis. W owych refleksjach odnajdywane są reminiscencje nawiązujące do epoki wspólnoty rodowo-plemiennej, co miało uzasadniać uniwersalizm najstarszych filozoficznych wizji polis. Przedfilozoficzne odwzorowania świata zostały więc przysposobione przez pierwsze koncepcje prawno-naturalne, co oznaczało, że polis (wspólnota polityczna) okazała się produktem natury, elementem kosmosu (częścią całości). To była koncepcja pitagorejska. Ale też naturalny charakter polis przedstawiały inne podejścia, np. Ksenofanesa czy Heraklita. Ujęcia te wskazywały na

37 J. Gajda, Prawo natury i umowa społeczna w filozofii przedsokratejskiej, Wrocław 1986, s. 30-31. 
oczywistość naturalnego wymiaru państwa i podporządkowania interesu jednostki dobru wspólnoty. Konieczność życia w polis, dla której modelem jest kosmos, oznacza zajęcie stanowiska przez myśl filozoficzną wobec istniejącego, konkretnego świata społeczno-politycznego, państwa, prawa i sytuacji człowieka. To podejście oznacza, że archaiczna filozofia nie opierała swojej racjonalizacji wyłącznie na przedfilozoficznych opisach. W każdym razie poszukiwania filozoficzne projektowały różne racjonalne uzasadnienia, jeżeli chodzi o pozycję człowieka w polis, jego podporządkowanie państwu i prawu. Oznaczało to też określone podejście do dzielności (arete), tzn. oczekiwano aktywności ze strony obywatela. W racjonalizacji takiej postawy w odniesieniu do życia politycznego odnajdywane są fundamenty myśli politycznej38.

Koncepcja natury i jej prawa zainteresowała się, jak wspomniano, także sferą społeczną i polis. W tym zakresie wizje filozoficzne przede wszystkim racjonalizowały polis i jej prawa (nomoi). Zaznaczono, że ujęcie w formie pisanej prawa zwyczajowego (długotrwały proces kodyfikacji) doprowadziło do pojawienia się prawa państwowego (nomos), którego rola polegała na dostarczeniu podstaw dla postępowania wspólnoty ludzkiej i działania polis, na wskazaniu polis jako bytu, z którym ludzie mieli wiązać swój sens. W świadomości mieszkańców polis cechą nomos było posiadanie zarówno treści prawa boskiego (themis) pochodzącego od Zeusa, jak i treści pochodzącej od dike (możność dochodzenia swoich uprawnień). Prawa są podstawą polis, one bowiem kształtują jej strukturę i działanie. Spisania tego prawa, jak wspomniano, mógł dokonać tylko prawodawca, tj. osoba, która posiadła mądrość - poznała prawo natury i zgodnie z nim stworzyła prawo (nomos) umożliwiające właściwe działanie polis ${ }^{39}$.

Oczekiwanie zgodności prawa polis z prawem natury zostało wyrażone w tych archaicznych koncepcjach filozoficznych, które podjęły racjonalizację państwa i prawa. Na problem wspomnianej zgodności zwrócili uwagę krytykujący istniejące nomoi pitagorejczycy, Ksenofanes czy zwłaszcza Heraklit ${ }^{40}$.

Zapewne w kodeksach, które stworzyli pierwsi prawodawcy, spisano zwyczaje konkretnej wspólnoty, wprowadzono do nich regulacje inspirowane wiedzą o unormowaniach zawartych $\mathrm{w}$ aktach prawa spisanego $\mathrm{w}$ innych poleis, a wreszcie zaproponowano różne nowości, aby rozwiązać bieżące problemy społeczne. Ale

38 Ibidem, s. 163-165 i powoł.: W. Kornatowski, Uniwersalizm i indywidualizm poznawczy w greckiej teorii państwa oraz idem: Przesłanki nauki o państwie w klasycznej Grecji; Pojęcie państwa w świetle badań teoretycznych.

39 J. Gajda, op. cit., s. 165-166.

40 Ibidem, s. 166, 54; J. Oniszczuk, Sprawiedliwość jako wieczna i regularna wymiana wedtug inteligentnej miary. Poszukiwanie prawa, [w:] J. Osiński (red.), Kapitalizm a sprawiedliwość społeczna, Warszawa 2016, s. 13-67. 
powoływanie na prawodawców uznanych mędrców i filozofów oznacza, że poglądy tych osób nie były obojętne dla społeczności. I zapewne w spisanych aktach prawa zostały też odzwierciedlone interpretacje i koncepcje społeczne o charakterze filozoficznym. Inaczej mówiąc, kodeksy zawierają informację o poglądach myślicieli-prawodawców.

Można przypomnieć, że we wcześniejszej epoce homeryckiej nie istniał jakiś rozwinięty system prawa i sądów, ale pewien zbiór tabu i obyczajów oraz publiczny arbitraż. Jeżeli chodzi np. o procedurę prawną tego sądu o charakterze arbitrażowym, to przedstawiana jest $\mathrm{w}$ formie obrad publicznych na podobieństwo obrad zgromadzenia. I w tym przypadku występują członkowie rady starszych jako mediatorzy i w swoim imieniu. W tym postępowaniu nie jest możliwe narzucenie stronom decyzji, natomiast do rozwiązania sprawy dochodzi przez przyjęcie rozstrzygnięcia przez obie strony sporu. Później arbitraż został zastąpiony przez sąd z kodeksem chronionym przez publiczne sankcje ${ }^{41}$. W późniejszym zaś skodyfikowanym prawie, jak wspomniano, pojawiła się próba pewnej uniwersalizacji rozwiązań. Na przykład o prawodawstwie Solona mówiono, że dążyło do uporządkowania doświadczeń „pokoleń zawodowych rozjemców”. Wprowadzało ład w świecie interpretacji zwyczajów przez starszą arystokrację. Ale też tę władzę starszych ograniczał postęp we wprowadzaniu zasady równości obywateli wobec prawa $^{42}$, a więc spisane nowe prawo sprzyjało demokratyzacji ustroju polis. Żądanie spisania prawa oznaczało, że co do zasady, chodziło o pojawienie się regulacji o charakterze bezstronnym i bezosobowym, a także traktującym obywateli równo. To na podstawie takiego prawa stosowanego bezstronnie wyobrażano sobie sprawiedliwość w polis. Orzecznictwo miało być sprawiedliwsze w porównaniu zwłaszcza do wyroków sędziów arystokratycznych, którzy stosowali znane im (i dowolnie interpretowane) reguły zwyczajowe. O owych spisanych przez prawodawców prawach, ze względu na ich szczególny charakter, treść i osobę twórcy, można powiedzieć, że stanowiły pierwsze konstytucje.

Co istotne, to z pojawieniem się bezosobowego i uniwersalnego systemu prawnego używającego środka oddziaływania w postaci orzekania wykształcił się powszechny regulator stosunków społecznych. Sens prawny wyraził się w nomos (umowa, konwencja) przeciw idei physis. To myślenie miało m.in. rozbudzić ogólną refleksję o charakterze naukowo-filozoficznym. Abstrakcyjna formuła prawa pojawiła się jako inspiracja dla myślenia filozoficznego. Mogło to nastąpić zwłaszcza

\footnotetext{
41 O. Murray, op. cit., s. 84-85.

42 Jako przykład podawana jest wypowiedź Solona: „Spisałem prawa złym na równi i dobrym/ Wszystkim tak samo prostej Dike/ poddałem".
} 
wówczas, gdy dzięki prawnemu uznaniu pojawił się monetarny pieniądz z kruszcu, tj. posiadający wytłoczony znak wskazujący na pewną umowną (prawną) wartość.

\section{Znaczenie monety i normy}

Jak dotąd nie zostało jednoznacznie ustalone, kiedy wybito pierwsze monety i jakie było bezpośrednie tego uzasadnienie. Można przypomnieć, że pojawienie się bitej monety w handlu poprzedzała wymiana, do której m.in. używano cennych metali, $\mathrm{np}$. w formie bryłek bądź sztabek czy też prętów żelaznych. Ten system zastępował powoli prosty handel wymienny. Gdy na tej bryłce wytłoczono godło, oznaczało to pojawienie się pieniądza monetarnego, bowiem temu znakowi towarzyszyła gwarancja wartości monety związana z miejscem pochodzenia. Pierwsza moneta okazała się być „zatwierdzonym przez zwyczaj” (nomisma) kawałkiem metalu. Te wynalezione w VII w. p.n.e. w Lidii bryłki traktowane w tradycji piśmienniczej starożytnych jako monety bito z elektronu już w okresie Midasa od ok. 700 r., zaś król Gyges (ok. 687-652 r. p.n.e.) miał dokonać normalizacji emisji bryłek odpowiednio do zabarwienia i określił ich wartość. Bryłki po 650 r. p.n.e. zostały zastąpione przez bite monety. Później monety z czystego złota i srebra wprowadził inny lidyjski król - Krezus (561-546 r. p.n.e.) ${ }^{43}$. Nie bez znaczenia dla pojawienia się po 650 r. monet $\mathrm{w}$ Jonii był zapewne fakt, że greckie poleis w Azji Mniejszej rozwijały się w sąsiedztwie królestw Frygii i Lidii. Ta ostatnia obejmowała swoimi wpływami różne greckie poleis, w tym tak znaczące jak Efez, a w pewnym stopniu także Milet ${ }^{44}$. I to w Efezie pod koniec VII w. p.n.e. miała pojawić się własna, bita moneta elektronowa. Jeżeli chodzi zaś o pierwsze srebrne monety na terenie Grecji właściwej (a niewykluczone, że w całej Helladzie), to ich bicie przypisywane jest Eginie (ok. 595 r. bądź ok. 580 r. p.n.e.). W Atenach własna moneta miała pojawić się ok. 575 r. p.n.e. ${ }^{45}$. Pogląd numizmatyczny określa wybicie monet w Eginie na ok. 570 r. i odpowiednio później w Koryncie i Atenach. Ale też znalezisko baryłek gładkich,

43 N.G.L. Hammond, Dzieje Grecji, Warszawa 1994, s. 174 i n.

44 Frygia pojawiła się w epoce Ludów Morza, w 2 poł. VIII w. panował w niej legendarny król Midas. Państwo Lidyjskie pod koniec wieku VII i w VI (królowie Alyattes, 617-560 i Midas) podporządkowało sobie miasta greckie. Ostatecznie jednak Lidia uległa w dużym stopniu hellenizacji, a nadto władcy Lidii nie wchodzili w sprawy podporządkowanych im miast. W VII w. ponownie zaczynają się też intensyfikować kontakty z Grecją właściwą (B. Bravo, E. Wipszycka, op. cit., s. 263).

45 O. Murray, op. cit., s. 312-313. Według Murraya wspomniane datowanie lidyjskich monet elektronowych bywa też uznawane za niepewne i dowodzi się, że ich bicie nastąpiło później, tj. w okresie między 625-600 r. p.n.e., bądź w okresie władzy króla Alyattesa II (ok. 617-560), czy nawet ok. 590 r. (pogląd numizmatyczny). 
„Wytłaczanych", żłobkowanych i bitych monet elektronowych ${ }^{46} \mathrm{w}$ fundamentach świątyni Artemidy w Efezie (depozyt fundacyjny pierwszej świątyni - z ok. 545 i z możliwością uzupełnienia przy budowie drugiej) sprawia, że pojawiły się rozbieżne oceny co do najstarszych emisji, tj. umieszczane są między 680 a 600 r. p.n.e. Nie wykluczają one nawet pierwszeństwa greckiego w wytworzeniu tego pieniądza. Najczęściej jednak uznaje się, że monety w dzisiejszym ich rozumieniu wybito w Lidii i także we wspomnianym Artemizjum w Efezie po 650 r. p.n.e. Wedle tej interpretacji po Jonii monety miały pojawić się na Eginie (ok. 625 r. p.n.e.), w Koryncie (ok. 610 r. p.n.e.) i w Atenach (ok. 600 r. p.n.e.). Pieniądz z Eginy był monetą obiegową na Peloponezie przez ponad dwa stulecia (system monetarny z Eginy uznało bowiem wiele greckich poleis $)^{47}$. $\mathrm{Z}$ kolei perska produkcja pieniądza zapoczątkowana została końcu VI w. p.n.e. Ze znacznym niekiedy opóźnieniem monety przyjmowały różne ludy śródziemnomorskie, np. Fenicjanie, Kartagińczycy czy Etruskowie. Upowszechnienie pieniądza monetarnego w basenie Morza Śródziemnego nastąpiło pod koniec VI w. p.n.e. Moneta stała się zjawiskiem charakterystycznym dla cywilizacji greckiej. Grecy pierwsi mieli docenić i wykorzystać wynalazek pieniądza monetarnego. Monety były bite niemal w każdym mieście i stanowiły manifestację własnej niezależności (polityczny sens monet). Wobec tego jednak, że każda moneta z kruszcu wyrażała dużą wartość, nie mogły one funkcjonować w obrocie detalicznym. Dlatego cenne monety nie tyle występowały jako środek w codziennym handlu, ale bardziej jako forma gromadzenia kruszcu. Co ważne, sens bicia przez państwo cennych monet wiązany jest bardziej z jego finansowymi zobowiązaniami (np. płace za prace, za dostawy dla armii) i z płatnościami na rzecz państwa (podatki, cła, kary grzywny). To z upływem czasu monety znalazły szersze zastosowanie także w handlu. W każdym razie brak monety zdawkowej (C.M. Kraay)

46 Elektron jest naturalnym stopem złota, srebra i niewielkiej ilości miedzi. Został najpierw znaleziony w Sardis (Lidia). Można tu dodać, że alternatywna chronologia numizmatyczna umieszcza wybicie pierwszych monet lidyjskich ok. 590 r., co miałoby oznaczać, że w Eginie monety pojawiły się nieco przed 570 r., a później w Koryncie. Jeżeli chodzi o srebrne monety ateńskie - tetradrachmy to pojawiły się ok. 510 r. (kopalnie w Laurion). Z tetradrachmą wiązane jest pojawienie się pewnego standardu, który zdominował obszar egejski zwłaszcza po 322 r. Wcześniej taka standaryzacja (najwcześniejsza) srebrnej monety miała zapewnić powodzenie pieniądzowi bitemu w Eginie. Serii monet wybijanych w Eginie o różnej wadze przypisuje się nawet znaczenie dla rozwoju gospodarki opartej na handlu. Były one do ostatniego ćwierćwiecza V w. traktowane jako międzynarodowy środek wymiany. Zob. M. Cross, The Creativity of Crete. City States and the Foundation of the Modern World, Oxford 2011, s. 138.

47 N.G.L. Hammond, op. cit., s. 174-175, 766 i powołana wypowiedź Arystotelesa w sprawie początków systemu monetarnego Lidii i Eginy: „Do celów wymiany ludzie uzgodnili między sobą, że będą dawać i przyjmować materiały pożyteczne same w sobie i łatwe do zastosowania w życiu codziennym, takie jak żelazo, srebro i inne metale; początkowo określały je tylko wymiary i waga, lecz później zaczęto je stemplować, by uniknąć potrzeby mierzenia, ponieważ stempel wskazywał odtąd ilość zużytego metalu". 
uznaje się za znaczący argument przeciw początkowej obecności monety w drobnym handlu detalicznym ${ }^{48}$. Pieniądz monetarny z kruszcu nabrał większego znaczenia w pierwszej kolejności w handlu hurtowym (dalekomorski). Natomiast w drobnym obrocie ów pieniądz upowszechnił się po pojawieniu się monety zdawkowej z brązu na przełomie VI i V w.

Wynalezienie w epoce archaicznej środka wymiany w postaci monet bitych ze szlachetnych kruszców nabrało, jak wspomniano, ogromnego znaczenia dla relacji handlowych, ich intensyfikacji i rozmiaru. Innowacja ta wpłynęła nie tylko na życie handlowo-gospodarcze, ale także na przemiany stanu umysłowego Greków. Znormalizowane baryłki elektronu i takie też późniejsze monety zmieniły sposób podejścia do własności, do ujęcia jej w prawie, polityce poleis i kulturze. Wynalazek lidyjski - miernik w postaci pieniądza monetarnego (elektron) sprawil, że cechą epoki archaicznej stał się rozwój gospodarki monetarnej. Monety zaczęły zmieniać oceny dotyczące wartości rzeczy. Zastąpiły one inne sposoby mierzenia wartości. Człowiek mógł przedstawiać całokształt tego, co posiadał, swoje gospodarstwo w kategoriach pieniężnych. Mierzenie wartości polegającej na bezpośrednim porównywaniu dwóch towarów zostało zastąpione przez uniwersalny miernik pośredniczący (umowny), umożliwiający określenie wartości każdej rzeczy. Szacowanie za pomocą czynnika pośredniczącego - pieniądza - wyrażało nowy stan myślenia oceniającego, tj. takie, które miało miejsce w oderwaniu od przypadku porównywania konkretnych rzeczy. W ten sposób dochodziło więc do rozwoju myślenia abstrakcyjnego. Można tu jednak odnotować też raczej odosobniony pogląd kwestionujący pieniądz monetarny jako w prowadzający powszechnie rewolucyjne następstwa w zakresie wartości, handlu i bogactwa ${ }^{49}$.

W każdym razie w przypadku uznania rewolucyjności monety można powiedzieć, że infrastrukturze komunikacyjnej (swoiste morskie autostrady) ogromnie ułatwiającej wymianę handlową, kulturalną i podróżowanie sprzyjała swoista infrastruktura pieniądza monetarnego, za którą stał rozwój myślenia abstrakcyjnego i zaufania do symbolicznych znaków na monetach z kruszcu wyrażających wartość.

Z wykształceniem abstrakcyjnego i powszechnego pieniądza monetarnego z kruszcu pojawiła się wartość materialna wyrażana też symbolicznie. Moneta ze

48 B. Bravo, E. Wipszycka, op. cit., s. 208-209 i m.in. powol. praca: C.M. Kraay (Archaic and Classical Greek Coins).

49 Niekiedy (np. Hans van Wees) wypowiadany jest pogląd, że moneta oznaczała tylko bardziej wygodny środek wymiany. Bierne podejście państwa do pieniądza interpretowane jest zatem jako jego zainteresowanie dostawami, a nie prywatnym handlem. Zatem duży handel i wspieranie kupiectwa oznacza, że państwo w tym zakresie dostrzegało pewne dobro i rozumiało znaczenie własnej aktywności w obszarze pieniądza. Zob. M. Cross, op. cit., s. 170 i powoł. H. van Wees (The Economy). 
złotego kruszcu okazała się nie tylko konkretną, nadającą się do wymiany rzeczą, ale też abstrakcyjnym kryterium pomiaru - standardem umożliwiającym ocenę wartości rzeczy nadających się do wymiany. Moneta pojawiła się zatem jako równowartość (ekwiwalent) pewnego dobra, ale też jako powszechny regulator (na podobieństwo prawa, j.w.) Jej wymiar symboliczny odnosi się do umownej formy pieniądza w gospodarce. Sens monety został nawet zinterpretowany, podobnie jak prawo, jako wyraz zwycięstwa nomos (umowy, konwencji) nad ideą physis (materia). Wejście w życie systemu monetarnego było możliwe w archaicznym świecie polis ze względu na osiągnięty poziom społeczny i gospodarczy, zwłaszcza handlowy (wymiana morska). Wykształcającemu się systemowi monetarnemu towarzyszył rozwój zrozumienia pojęcia powszechnej równowartości. System monetarny oderwał się więc od osób i zaproponował monetę jako uniwersalny środek wymiany. Charakterystyczna dla systemu monetarnego bezosobowość i uniwersalność cechuje też system prawny. I to pojawienie się pisanego systemu prawnego umożliwiło wykształcenie złożonego systemu monetarnego. Wspomniane cechy okazały się też mieć, jak wspomniano, znaczenie dla myślenia naukowo-filozoficznego. Jako przykład zainspirowania się cechami systemu monetarnego i prawnego podawana jest zwłaszcza heraklitańska koncepcja, jej opis logosu i ognia. I mimo, że owa filozofia nie korzysta wprost z pojęć nomos i physis, to ocenia się, że podjęła ona kwestię opozycji między tymi kategoriami ${ }^{50}$. System monetarny umożliwiał wykształcenie i rozwój pojęcia uniwersalnego, światowego równoważnika. Monety wyrażały przejście od bezpośredniej wymiany towarowej do umownej za pomocą uznania wartości monet. Monety oznaczają przejście od prywatnego wartościowania na rzecz rozwoju bardziej ogólnego systemu wartości. Pojęcie uniwersalnego ekwiwalentu, równoważnika (równowartości) czy też standardu pomiaru zawiera pewną drogę prowadzącą do filozoficznych koncepcji wymiany wartości w kosmicznej ekonomii ${ }^{51}$.

Można więc powiedzieć, że myślenie naukowo-filozoficzne, a więc o wymiarze abstrakcyjnym, pojawiło się tam, gdzie doszło m.in. do wykształcenia abstrakcyjno-ogólnego pisanego systemu prawa cywilnego i systemu wyrażającego konwencjonalną wartość za pomocą pieniądza monetarnego. Najwyższy poziom rozwoju gospodarczego osiągnęły poleis Azji Mniejszej, a zwłaszcza Milet, w którym pojawili się pierwsi znani filozofowie.

Z wykształceniem się systemu pieniądza monetarnego, zwłaszcza tzw. drobnego, nastąpiły zmiany w sytuacji społeczno-politycznej polis. Cechuje je odchodzenie od dominacji archaicznej ideologii arystokratycznej. Wedle owej koncepcji posia-

\footnotetext{
50 A.W. Nightingale, The Philosophers in Archaic Greek Culture, [w:] H.A. Shapiro, Introduction, [w:] H.A. Shapiro (red.), The Cambridge Companion to Archaic Greece, Cambridge 2007, s. 187-188.

51 Ibidem, s. 172.
} 
danie cennych metali oznaczało posiadanie podstawowych i niezmiennych wartości. Miało dowodzić „naturalnej” wyższości arystokracji. Natomiast w monetach odnajduje się mechanizm kwestionowania pierwszorzędności owej naturalnej wyższości, gdyż środek płatniczy, jakim okazały się pieniądze (nomisma), działał w myśl społecznej konwencji (dopuszczał zmienność). Według opisu Kurke’a pieniądz monetarny przełamywał monopol arystokracji na cenne dobra, które krążyły w formie darów (physis) w zamkniętym kręgu tej warstwy, zapewniając jej hierarchiczne znaczenie. Natomiast monety wprowadziły cenne metale do ogólnego obrotu pod symboliczną władzą polis. Inaczej mówiąc, w takich oznakowanych monetach polis odnajdywane jest przeciwstawienie się tzw. naturalnej władzy arystokracji. Mimo więc, że monety związane były z cennym metalem, to jednak wyrażały już, jak wspomniano, zwycięstwo koncepcji nomos w stosunku do physis ${ }^{52}$. Moneta w miejsce "naturalnej” najwyższej roli arystokracji proponowała w sprawach zamożności „demokratyzację", wprowadzając wyrównywanie.

\section{Zakończenie}

Sensem umysłowych poszukiwań człowieka refleksyjnego, filozofującego okazała się reguła. Chodziło o zasadę kierującą światem tzw. naturalnym, fizycznym (kosmos) i relacjami między ludźmi. Pisemna abstrakcyjna norma prawna (nomos), wytworzona dla obrotu gospodarczego i własności (prawo cywilne) wyrażonej abstrakcyjnie w pieniądzu, nie była obojętna dla zainicjowania i rozwoju myślenia naukowo-filozoficznego. I tylko dla porządku należy dodać, że innymi fundamentalnymi warunkami rozwoju nauki i filozofii była wolność, równość i uznanie dla inności, a także nieortodoksyjny charakter wierzeń (mitów). Te zapewniała zaś obywatelska, kosmopolityczna i rozwinięta gospodarczo polis, zwłaszcza demokratyczna. Owe warunki rozwoju nauki i okazały się uniwersalne i ponadczasowe.

\section{Bibliografia}

Arystoteles, Polityka, Warszawa 2004.

Bravo B., Wipszycka E., Historia starożytnych Grekóww, t. 1, Do końca wojen perskich, Warszawa 1988.

Chadwick J., Odczytanie pisma linearnego B, Warszawa 1964.

Cross M., The Creativity of Crete. City States and the Foundation of the Modern World, Oxford 2011.

52 Ibidem, s. 188 i powoływana praca: L. Kurke (Coins, Bodies, Games, and Gold). 
Gadamer H.G., Początek filozofii, Warszawa 2008.

Gajda J., Prawo natury i umowa społeczna w filozofii przedsokratejskiej, Wrocław 1986.

Hammond N.G.L., Dzieje Grecji, Warszawa 1994.

Hansen M.H., Polis. Wprowadzenie do dziejów greckiego miasta-państwa w starożytności, Warszawa 2011.

Herodot, Dzieje, Warszawa 2004.

Hezjod, Prace i dnie, Wrocław 1952.

Homer, Odyseja, tłum. L. Siemieński, oprac. Z. Kubiak, Warszawa 1990.

Krawczuk A., Mity, mędrcy, polityka, Warszawa 1975.

Krońska I., [w:] Diogenes Laertios, Żywoty i poglądy stynnych filozofów, Warszawa 2006.

Lengauer W., Religijność starożytnych Greków, Warszawa 1994.

Lengauer W., Starożytna Grecja okresu archaicznego i klasycznego, Warszawa 1999.

Murray O., Narodziny Grecji, Warszawa 2004.

Nightingale A.W., The Philosophers in Archaic Greek Culture, [w:] H.A. Shapiro, Introduction, [w:] H.A. Shapiro (red.), The Cambridge Companion to Archaic Greece, Cambridge 2007.

Oniszczuk J., Hezjod: prefilozofia pracy, sprawiedliwości i hybris, [w:] M. Latos-Miłkowska, Ł. Pisarczyk (red.), Prawo pracy między gospodarka a ochrona pracy. Księga jubileuszowa Profesora Ludwika Florka, Warszawa 2016.

Oniszczuk J., Sprawiedliwość jako wieczna i regularna wymiana wedtug inteligentnej miary. Poszukiwanie prawa, [w:] J. Osiński (red.), Kapitalizm a sprawiedliwość spoteczna, Warszawa 2016, s. 13-67.

Oniszczuk J., Użyteczność wiedzy, władzy, państwa i prawa w poszukiwaniach pitagorejskich, „Państwo Prawne” 2015, 1(5), s. 7-57.

Reale G., Historia filozofii starożytnej, t. 1, Lublin 2008.

Stamatellos G., Introduction to Presocratics, Malden-Oxford 2012.

Szulczewski G., Aporie filozofii a kondycja racjonalizmu, Warszawa 2006. 